\title{
THE DEVELOPMENT OF TOURISM AT MILITARY-HISTORICAL STRUCTURES AND SITES - A CASE STUDY OF THE BUILDING COMPLEXES OF PROJECT RIESE IN THE OWL MOUNTAINS
}

\author{
ELŻBIETA STACH, ANETA PAWŁOWSKA, ŁUKASZ MATOGA \\ Jagiellonian University, Institute of Geography and Spatial Management, \\ Department of Tourism and Health Resort Management
}

\begin{abstract}
Mailing address: Elżbieta Stach, Jagiellonian University, Department of Tourism and Health Resort Management, 7 Gronostajowa Street, 30-387 Kraków, tel.: +48 12 6645295, fax: +48 12 6645385, e-mail: elzbieta.stach@uj.edu.pl
\end{abstract}

\begin{abstract}
Introduction. During WWII, the Owl Mountains were the site of a large-scale military investment codenamed Riese. This project called for the construction of underground passages using concentration camp prisoners as laborers. Material and methods. On the basis of terrain inventory, analysis was conducted of the tourism management of six military-historical complexes of Project Riese and their environs. Tourists were polled to determine how attractive they found one of thesethe Rzeczka complex - as a tourist destination. Results. The results obtained in the study led to the conclusion that the complexes' infrastructure and tourist attractions meet the needs of tourist activity in the area. In the case of the municipalities where complexes are located, it was determined that they are not being adequately developed. Conclusions. At present, the Project Riese complexes are seeing the development of various forms of tourism. An important problem with the development of tourism there is the conflict between the need to protect the environment and cultural heritage and the development of commercial and recreational tourism services.
\end{abstract}

Key words: military cultural tourism, dark tourism, tourism development, Riese Project, Owl Mountains

\section{Introduction}

On the Polish border there are currently around 16,000 military-historical structures from various years and periods [1]. These assume various architectural forms and serve as material traces of history, battles and martyrdom. They also constitute expressions of the technical, engineering and architectural ideas of their day. Among many structures of this kind, the underground complexes from WWII located in the Owl Mountains and built as part of Project Riese are an object of interest to tourists.

Project Riese was built in the 1940s in the Owl Mountains, a range of medium-sized mountains belonging to the Central Sudetes Mountain range. There are currently six complexes in the mountains that comprised Project Riese. These include bunkers, underground structures and adits named Rzeczka, Włodarz, Osówka, Jugowice, Soboń and Sokolec (fig. 1, tab. 1). According to Polish administrative divisions, these structures are located in three municipalities (tab. 1).

The Rzeczka, Włodarz and Osówka adits have been placed under legal protection as "an area for observing the Riese archaeological complex from WWII" [2]. Attempts have also been made to subject reomorphic granitoids in Osówka to legal protection as a site for geological documentation [3]. Furthermore, the region where Project Riese complexes are located is valuable from an environmental perspective and is subject to various forms of environmental protection pursuant to Polish law. This is an important aspect of the region's attractiveness for tourists. The Owl Mountains Landscape Park and the Bukowa Kalenica Nature Reserve have been established on this land. In additional, a significant percentage of the Owl Mountains region belongs to the Nature 2000 European Ecological Network, which protects habitats and wintering locations for bats; this area also partly includes Riese Project adits.

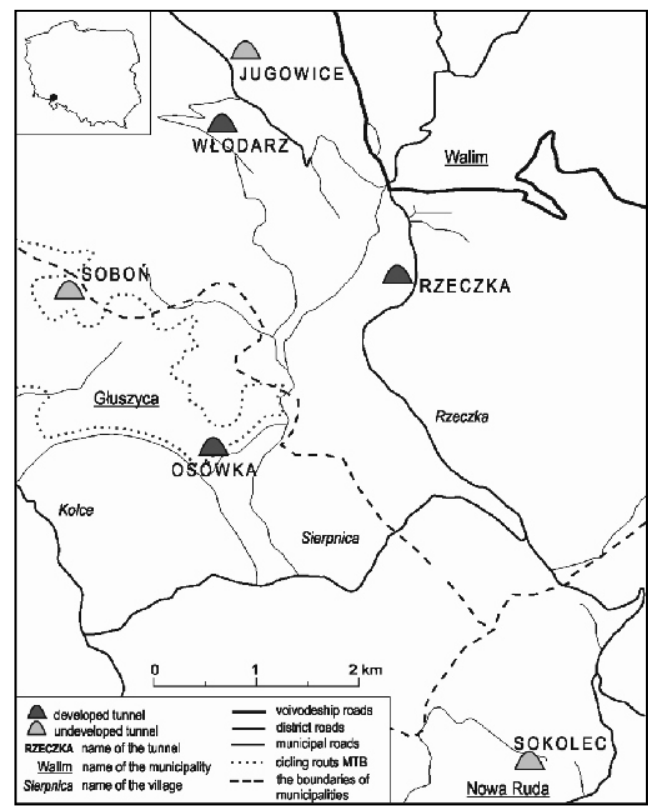

Source: original reports based on fieldwork

Figure 1. Distribution of the Project Riese complexes in the Owl Mountains 
Table 1. General information on the Project Riese complexes

\begin{tabular}{|c|c|c|c|c|c|c|}
\hline $\begin{array}{c}\text { Name } \\
\text { of complex }\end{array}$ & $\begin{array}{c}\text { Location } \\
\text { (municipality) }\end{array}$ & $\begin{array}{l}\text { No. of } \\
\text { entries }\end{array}$ & $\begin{array}{l}\text { Length } \\
\text { (m) }\end{array}$ & $\begin{array}{l}\text { Area } \\
\left(\mathrm{m}^{2}\right)\end{array}$ & $\begin{array}{c}\text { Volume } \\
\left(\mathrm{m}^{3}\right)\end{array}$ & $\begin{array}{c}\text { Volume } \\
\text { Administrator }\end{array}$ \\
\hline Rzeczka & Walim & 3 & 560 & 2600 & 14700 & \begin{tabular}{|c|} 
Office of the Walim \\
Municipality, \\
The Centre for Tourism \\
and Culture
\end{tabular} \\
\hline Włodarz & Walim & 4 & 2955 & 10885 & 40520 & $\begin{array}{l}\text { Private Company, } \\
\text { The "Giant" Museum } \\
\text { and Tourism Center } \\
\end{array}$ \\
\hline Osówka & Głuszyca & 3 & 1790 & 6480 & 26740 & \begin{tabular}{|c|} 
Private company, \\
The Underground City \\
of Osówka
\end{tabular} \\
\hline Jugowice & Walim & 7 & 460 & 1360 & 4200 & $\begin{array}{l}\text { Office of the Walim } \\
\text { Municipality }\end{array}$ \\
\hline Soboń & Głuszyca & 3 & 700 & 1900 & 4000 & $\begin{array}{c}\begin{array}{c}\text { Office of the Głuszyca } \\
\text { Municipality }\end{array} \\
\end{array}$ \\
\hline Sokolec & Nowa Ruda & 4 & 860 & 2450 & 7100 & $\begin{array}{l}\text { Office of the Nowa } \\
\text { Ruda Municipality }\end{array}$ \\
\hline
\end{tabular}

Source: original reports based on fieldwork.

Large-scale military investment, codenamed Riese, was implemented from 1943-45 to support the wartime activities of the Third Reich. Underground transport passages, adits and chambers were excavated. Their purpose remains unexplained to this day $[4,5]$.

Some historical accounts claim that the complex was to serve as Hitler's main headquarters [6]. Additional functions are also cited, such as the planned creation of shelters and bunkers, or even the relocation of V1 and V2 rocket production to this site. Other hypotheses mention the presence of uranium ore deposits in the vicinity, which would be used to produce nuclear weapons $[4,5,7]$. However, the investment codenamed Riese was never completed, and its ultimate purpose remains a mystery to this day.

The structures of Project Riese are a mute witness to the death and tragedy of many people; they were built using prisoners from the former Gross-Rosen concentration camp in present-day Rogoźnica, along with its 13 branches located in the vicinity of the construction site. Around 5000 people died during construction due to starvation, illness or structural collapses $[8,9]$. The site of the former Gross-Rosen concentration camp was listed on the monument registry of the National Heritage Board of Poland in 1963. The camp is currently the site of a museum created in 1983. Other sites where prisoners are commemorated include the cemetery in the Owl Mountains region, which is subject to legal protection (the cemetery of the Victims of Fascism in the Głuszyca municipality and the Quarters of the Victims of NAZI Terror in the Walim municipality).

In recent years, the underground complexes of Project Riese have come to play an increasingly important role in building tourism in the region. Three of the six complexes: Rzeczka, Włodarz and Osówka have been opened to the public. The remaining complexes, because they are in poor technical condition and located in areas subject to landslides, are not open to tourists. Several forms of tourism have developed in the area, e.g. military cultural tourism, dark tourism and urban exploration, as well as other ways of spending free time, such as geocaching. One element that makes the area attractive for tourists is the fact that the purpose of the complexes remains unexplained.

The development of tourism based on military-historical elements connected with martyrology, as in the case of the Project Riese complexes, requires purposeful activity, both in making the place available to tourists and in raising visitor awareness of the region's history. This is one reason why the goal of this article is to characterize tourism development of the Project Riese complexes. Attention has also been paid to tourists' opinions regarding the attractiveness of the Rzeczka complex and to their reasons for visiting. The spatial scope of the studies also included the immediate vicinity of the complexes, as well as the municipalities where they are located.

\section{Tourism involving military-historical objects as a subject for scholarly studies}

Military-historical structures and locations that today are part of our cultural heritage are eagerly visited by tourists from all parts of the world $[10,11,12]$. Due to their great historical value, they influence the attractiveness of locations and regions, as confirmed in numerous studies concerning their tourism potential $[13,14]$. This type of structure serves as a basis for the development of different forms of tourism, especially military cultural tourism [15] and dark tourism. In many cases, both of these forms of tourism involve traveling to places connected with wartime activities. This may arouse controversy; in particular, it seems unethical to consider these places tourist attractions $[16,17,18,19]$. On the other hand, traveling to military-historical structures and locations involves familiarization with the history of a given place, and is therefore connected with the transfer of knowledge that is of universal value and serves to educate society [20,21, 22].

Tourism to military locations and structures can play a crucial role in shaping attitudes, especially those of the younger generation. This is because it gives tourists an opportunity to acquaint themselves with a difficult and painful history. A completed journey may serve as an occasion for reflection and lead to contemplation of the dramatic consequences of war $[23,24]$.

However, military-historical structures and locations are almost always connected with war, as well as with death and human suffering. Therefore, the desire to visit places connected with martyrdom and battle may also constitute an objective for tourists [25]. Such visits are now termed dark tourism or thanatourism [26]. Dark tourism is an example of a niche product on the tourism market [27]. The increasing importance of this form of tourism has been analyzed in the scholarly literature from social, cultural, political and historical perspectives [26, 28, 29]. Individuals participating in dark tourism or thanatourism are interested in, among other things, places where famous people died or lie buried, concentration camps, disaster sites and even places and structures connected with cruelty and martyrdom $[20,26,30,31,32,33]$.

In addition to acquainting themselves with historical accounts and locations connected with death, another motivation for going on a journey might be the desire for active exploration. Military-historical objects can meet this need, thus becoming a place for conducting extreme forms of recreation - often in places that are deserted or inaccessible to visitors. Examples include urban exploration and geocaching [34, 35].

\section{Material and methods}

The choice of research area was dictated by the increasing importance of military cultural tourism in Poland and by the large number of activities on the part of managers and local governments aimed at developing tourism for the underground complexes of Project Riese. The analysis of tourism development conducted in this article concerns the underground complexes that are open to visitors, as well as accommodations, food and beverage services and accessibility.

The basic research method was a case study conducted in two phases. The first involved examining literature and 
source materials concerning the problem in question. To determine the state of tourism development in the region in question, statistical data from the Central Statistical Office was consulted, as were local strategies drawn up by the individual municipalities. The second research phase consisted of a field inventory, which made it possible to determine the complexes' current state of development, including how they are exhibited and made available to tourists. Terrain studies also facilitated analysis and assessment of the environs of structures and the accompanying infrastructure. To determine tourism motivations and learn the opinions of visitors regarding the attractiveness of the location, a survey was conducted in the Summer of 2011 using a random selection of tourists departing the Rzeczka complex. One hundred adults were asked to complete the survey. In choosing respondents, a sampling procedure involving a table of random numbers was applied.

\section{Results}

\section{The development of tourism in the Project Riese complexes and their environs}

The development of tourism in the complexes that have been opened to tourists, i.e. Rzeczka, Włodzarz and Osówka, involves tourist routes offering guided tours, including water and climbing routes as well as museum exhibitions on historical and martyrological themes (tab. 2). It also involves theme packages that include educational, recreational and athletic activities addressed to different groups, e.g. elementary school children and high school students, families with children and company employees. Paintball fields and recreational infrastructure are located in the vicinity of the structures. There are also numerous hiking and bicycle trails and educational walks in the vicinity.

The remaining three adits, Jugowice, Soboń and Sokolec, have not undergone tourism development and are closed to the public. They are located on terrain that is subject to landslides, and their entrances are caved in. However, these locations are attractive to cavers and practitioners of unconventional forms of tourism and recreational activity. Examples of such forms include urban exploration (expeditions to structures and locations that are abandoned and difficult to access) and geocaching (an outdoor game that involves using GPS navigation to find hidden containers).

The grounds of the Project Riese complexes are the site of cultural and entertainment events, as well as events involving local history. Since 2008, the "Explorers' Convention" has taken place regularly in the Museum of the Walim Adits. During the event, participants visit adits and are given an opportunity to observe various underground exploration techniques and attend performances by historical reenactment groups. There are also theatrical productions that serve as symbolic homage to the prisoners who built the complexes. In Włodarz, at the beginning of the Summer season, there is a yearly outdoor event that includes a free visit to the structure. In Osówka, by contrast, the events are most often one-time affairs, for example the European Heritage Days or the International Campers Rally.

Development of accommodations and food and beverage services in the municipalities where the Project Riese complexes are located $[36,37]$ is relatively more advanced than in the immediate vicinity of the adits themselves (tab. 3). A crucial role in the reception of tourism is played by the development of agrotourism (1814 places of accommodation in 2008). Hotels, motels and pensions account for a significantly lower percentage of spaces (147 rooms in 2012). Food and beverage services are provided primarily in places of accommodation located in the municipalities. There are also a few such places located directly beside the adits.
Table 2. Profile of tourism development of the Project Riese complexes

\begin{tabular}{|c|c|c|c|}
\hline \multirow{2}{*}{$\begin{array}{c}\text { Name } \\
\text { of structure } \\
\text { (year opened } \\
\text { to tourists) }\end{array}$} & \multirow{2}{*}{$\begin{array}{l}\text { Number } \\
\text { of adits }\end{array}$} & \multicolumn{2}{|c|}{ Tourism development } \\
\hline & & inside the structure & outside the structure \\
\hline 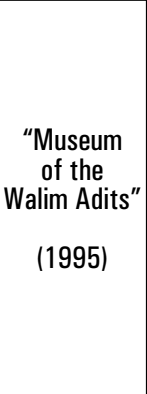 & 3 & $\begin{array}{l}\text { tourist footpath } \\
\text { - museum exhibitions on } \\
\text { WWII history, the history } \\
\text { of construction of the } \\
\text { structure and the former } \\
\text { Gross-Rosen concentration } \\
\text { camp "S } \\
\text { - in the "Great Hall", } \\
\text { an interactive exhibition } \\
\text { presenting prisoners' work } \\
\text { - in the "Concert Hall", } \\
\text { a multimedia simulation } \\
\text { of an Allied raid }\end{array}$ & $\begin{array}{l}\text { - a historical exhibition } \\
\text { connected with WWII and } \\
\text { the former Gross-Rosen } \\
\text { concentration camp } \\
\text { - a shop with souvenirs } \\
\text { - a restaurant } \\
\text { - free parking } \\
\text { - a rifle range and paintball } \\
\text { fields }\end{array}$ \\
\hline $\begin{array}{c}\text { “Włodarz" } \\
\text { (2004) }\end{array}$ & 4 & $\begin{array}{l}\text { - two tourism routes: } \\
\text { a footpath and a waterway } \\
\text { taken by boat } \\
\text { - climbing lines and } \\
\text { handholds } \\
\text { - museum exhibitions } \\
\text { on the history of the } \\
\text { Project Riese complexes } \\
\text { - a screening room } \\
\text { in the guardhouse }\end{array}$ & $\begin{array}{l}\text { - a museum exhibition } \\
\text { presenting military } \\
\text { equipment and vehicles } \\
\text { - a shop with souvenirs } \\
\text { - a seasonal food \& beverage } \\
\text { point } \\
\text { - two parking lots: } \\
\text { free and private, paid } \\
\text { - a rifle range and paintball } \\
\text { fields }\end{array}$ \\
\hline $\begin{array}{c}\text { "The } \\
\text { Underground } \\
\text { City } \\
\text { of Osówka" } \\
\text { (1998) }\end{array}$ & 3 & \begin{tabular}{|l|} 
- three tourism routes: \\
a footpath, a waterway \\
taken by boat and an \\
extreme route involving \\
crossing a suspension \\
bridge, a crossing by \\
landing craft, and \\
underground exploration \\
using a metal detector \\
- military-themed museum \\
exhibitions \\
exhibitions connected with \\
the history of the former \\
Gross-Rosen concentration \\
camp
\end{tabular} & $\begin{array}{l}\text { - an educational nature } \\
\text { trail for children and } \\
\text { students relating to the } \\
\text { history of Project Riese, } \\
\text { the geology of the } \\
\text { Owl Mountains, } \\
\text { silver-extraction } \\
\text { techniques and legends } \\
\text { of Lower Silesia } \\
\text { - a shop with souvenirs } \\
\text { - a restaurant } \\
\text { - paid parking }\end{array}$ \\
\hline
\end{tabular}

Source: original reports based on fieldwork.

Table 3. Accommodations in the municipalities of Walim, Nowa Ruda and Głuszyca in 2008 and 2012

\begin{tabular}{|c|c|c|c|}
\hline \multirow{2}{*}{ Accommodation } & \multicolumn{3}{|c|}{ Name of municipality } \\
\cline { 2 - 4 } & Walim & Nowa Ruda & Gluszyca \\
\hline Number of buildings providing accommodation & 13 & 6 & - \\
\hline including hotels, motels and pensions & 2 & 2 & - \\
\hline remaining & 11 & 4 & - \\
\hline Number of spaces & 420 & 365 & - \\
\hline including hotels, motels and pensions & 77 & 70 & - \\
\hline remaining & 343 & 295 & - \\
\hline Number of agrotourism estates* & 30 & 25 & 10 \\
\hline including number of spaces & 500 & 1133 & 181 \\
\hline
\end{tabular}

* Data from 2008; Source: original report drawn up on the basis of the Strategy of the Owl Mountains Subregion and Database of Local Data of the Central Statistical Office.

\section{Accessibility of the Project Riese complexes}

A separate yet equally important question concerning the region's attractiveness to tourists is one of transport infrastructure. The accessibility of the complexes may be assessed as adequate, especially given that they are located on land where excessive development of infrastructure could have a negative im- 
pact on the environment. The municipalities are located within range of two trans-border national roads (nos. 8 and 35) that lead to border crossings with the Czech Republic. Moreover, the A4 highway is located to the north, connecting Germany, Poland and the Ukraine. Access to the structures is possible thanks to an improved network of local roads. Bus transport is in the hands of private carriers, who primarily offer connections to big cities such as Wałbrzych, Wrocław, Nowa Ruda and Kłodzko. One factor that increases the internal accessibility of the region is the existence of regular local connections between municipalities. In the case of railway infrastructure, despite the existence of well-developed networks, most connections have been liquidated due to unprofitability. In recent years, attempts have been made to reactivate the narrow-gauge Walim Railway as a tourist attraction, but the project has not been implemented due to lack of funds [38].

Access to the complexes is supplemented by $210 \mathrm{~km}$ of bicycle trails and $169 \mathrm{~km}$ of hiking trails (according to data from the Tourist Association of the Municipalities of the Owl Mountains as of 2012). In 2003-04, a so-called "MTB Zone" (marathon bike zone) was created in the Owl Mountains, designating six trails measuring $150 \mathrm{~km}$ in total length for mountain bikes. This includes the "underground path", which runs through terrain where Sobon and Osówka are located. In addition, all of the structures of Project Riese, including branches of the former concentration camp Gross-Rosen, cemeteries and commemorative sites, are connected by the Trail of the Martyrs footpath $(18 \mathrm{~km})$.

\section{The opinions of tourists visiting the Rzeczka complex and the Museum of the Walim Adits}

In the light of the survey of visitors to the Museum of the Walim Adits, it turns out that $62 \%$ of visitors to the Rzeczka complex had no previous knowledge of the site. After visiting the structure, $82 \%$ of respondents rated the site as historically significant. The majority of visitors (63\%) declared interest in military-historical subjects. As their main motive for visiting, nearly half of the tourists indicated curiosity and a desire to learn the history of the place. A decidedly smaller group (14\%) consisted of individuals who were visiting the site due to a third-party recommendation or information obtained in the media. The third largest category of tourists (12\%) were individuals spending their vacation in the region and passing through the area.

The respondents were asked to rate transport accessibility, preparation of the routes for visitors, tour guide services, souvenir purchase opportunities and promotion of the complex in the media. Respondents awarded high marks for route preparation, souvenir purchase opportunities and access to the structure. The highest ratings were for tour guide services, with $94 \%$ of respondents rating them as very good, while promotion in the media received the lowest percentage, with $41 \%$ of respondents rating it as poor. After visiting Rzeczka, a clear majority, as many as $95 \%$ of respondents, assessed the site as attractive for tourism.

Tourists were asked whether they had visited other complexes of Project Riese, to which 75\% said yes, the majority having visited Osówka. The Soboń and Sokolec complexes had not been visited due to the fact that they have not been developed for tourism.

The results of the survey show that more than half (57\%) of the tourists who took part in the survey had not made use of any accommodation services. This clearly indicates the dominance of day-trip tourism. The remaining respondents reported having made use of agrotourism services, pensions and campgrounds.

\section{Discussion}

In the 1940s, the natural conditions and terrain features of the Owl Mountains led to this region being chosen as the site of the underground adits of Project Riese. Today, places connected with those events require legal protection and proper development, because they constitute an important historical document connected with martyrology. Tourism in the Owl Mountains should develop together with respect for natural, historical and cultural values. Therefore, the question arises whether the various forms of tourist activity taking place in that area should be organized.

The development of military cultural tourism should be acknowledged as a positive activity that benefits not only tourists, who are given the opportunity to come into contact with both unique historical heritage and a local community, but also entrepreneurs who develop businesses in the tourism sector. As these businesses develop, dark tourism becomes increasingly important. For this reason, activities connected with the development of tourism in the adits must strike a balance between respect for the history of the site and efforts to make the location available to visitors. This task is the responsibility of people who manage the structures; they are responsible for ensuring that rational development takes place.

In addition to military cultural tourism, whose objective is to educate tourists and familiarize them with history, there are also free-time activities aimed solely at recreation and entertainment, which runs counter to the ethical principles required in a place of martyrdom. This is why organizing activities like paintball or an International Campers Rally may create controversy.

On the one hand, these events increase tourism, but on the other, they lead to falsification of the authenticity of the site and reduce its historical value. Tourism based on cultural heritage must consider not only economic and marketing needs, but also the need to respect sites connected with martyrology and tragic events.

Rationally planned development of various forms of tourism and recreation may minimize conflicts of interest between entities from the private, public and social sectors that are active on the tourism market. In the case of the Project Riese complexes, this primarily concerns the owners or managers of these structures, private entrepreneurs, monument conservationists and institutions responsible for protecting the environment and the tourists themselves. Legal regulations governing protection of the natural and cultural environment are of strategic value in two regards: they involve protecting the environment for tourism and from tourism's negative effects.

\section{Conclusions}

1. The current state of all Project Riese complexes allows them to be divided into structures that have been developed for tourism (Rzeczka, Włodarz and Osówka) and those inaccessible to tourists (Jugowice, Soboń and Sokolec). Tourism development began in the mid 1990s on the initiative of local governments and private investors.

2. The fundamental form of tourism that is developing in vicinity of the structures is military cultural tourism, with dark tourism playing an increasingly important role. In addition, various events are organized here that fall under the category of active and recreational tourism.

3. Tourism development of underground adits, including tourism routes and museum exhibitions, has been expanded to include cultural and recreational events orga- 
nized on the terrain.

4. Accommodation, food and beverage locations and transport accessibility are adequate to the needs of tourism in the area. Tourism infrastructure in the immediate vicinity of the complexes is supplemented by offers from local entrepreneurs active in the municipalities where the structures are located.

5. Survey respondents rated tourism development and tourism offers as good and beneficial. This applies primarily to the preparation of routes for visitors, tour guide services, markings in the area for tourists and food and beverage services.

6. An important question when considering the development of military cultural tourism and the commercial development of the Project Riese complexes for tourism is the need to protect the area's environmental and cultural values, thus ensuring remembrance of the area's history - even if that history is difficult and painful.

7. When developing tourism in the area of the Project Riese complexes, care should be taken to respect the area's historical heritage, which should take precedence over economic benefits arising from the development of tourism services.

\section{Literature}

1. Kamińska E. (2007). With history in the background: fortress tourism. Wiadomości Turystyczne 150(24), 14-15. [in Polish]

2. Wojewódzki Urząd Ochrony Zabytków. (2011). A list of monuments in Wałbrzych county. http://wosoz.ibip.wroc.pl/public/ ?id=92696. [in Polish]

3. Koźma J., Cwojdziński S., Ihnatowicz A., Pacuła J., Zagożdżon P.P., Zagożdżon K.D. (2011). Possibilities for developing geotourism in the Lower Silesia Region based on selected projects concerning inventory and valorization of geological sites. In A. Żelaźniewicz, J. Wojewoda, W. Ciężkowski (Eds.), Mesozoic and Cenozoic of Lower Silesia (pp. 137-158). Wrocław: WIND. [in Polish]

4. Aniszewski M., Zagórski P. (2006). Military secrets. The underground world of the Owl Mountains. Kraków: Technol. [in Polish]

5. Cera J. (1998). Secrets of the Owl Mountains. Kraków: AURH Inter Cera. [in Polish]

6. Rostkowski J. (2010). The underground of the Third Reich: The secrets of Ksiqż, Wałbrzych and Szczawna-Zdroj. Poznań: Rebis. [in Polish]

7. Rdułtowski B. (2012). The hunt for Wunderwaffe - Hitler's secret weapon from the Owl Mountains. Kraków: Technol.

8. Mołdawa M. (1990). Gross-Rosen: Concentration camp in Silesia. Warszawa: Wydawnictwo Bellona. [in Polish]

9. Sula D. (2003). Labor camp Riese. KL branch Gross-Rosen. Wałbrzych: Muzeum Gross-Rosen. [in Polish]

10. Isaac R.K., Ashworth G.J. (2012). Moving from pilgrimage to dark tourism: leveraging tourism in Palestine. Tourism Culture \& Communication 11(3), 149-164. DOI: 10.3727/ 109830412 X13346876802194.

11. Gatewood J.B., Cameron C.M. (2004). Battlefield pilgrims at Gettysburg National Military Park. Ethnology 43(3), 193216. DOI: 1G1-122990743.

12. Smith V.L. (1998). War and tourism: an American ethnography. Annals of Tourism Research 25(1), 202-227. DOI: 10. 1016/S0160-7383(97)00086-8.

13. Henderson J.C. (2000). War as a tourist attraction: the case of Vietnam. International Journal of Tourism Research 2(4), 269-280. DOI: 10.1002/1522-1970(200007/08)2:4<269: :AID-JTR219>3.0.CO;2-A.
14. Winter C. (2011). Battlefield visitor motivations: explorations in the Great War Town of Ieper, Belgium. International Journal of Tourism Research 13(2), 164-176. DOI: 10. 1002/jtr.806.

15. Jędrysiak T., Mikos von Rohrscheidt A. (2011). Military cultural tourism. Warszawa: Polskie Wydawnictwo Ekonomiczne. [in Polish]

16. Dwork D., Van Pelt R.J. (1996). Auschwitz: 1270 to the present. New York: W.W. Norton.

17. Miller D.S., Gonzalez C. (2013). When death is the destination: the business of death tourism - despite legal and social implications. International Journal of Culture, Tourism, and Hospitality Research 7(3), 293-306. DOI: 10.1108/IJCTHR05-2012-0042.

18. Tunbridge J.E., Ashworth G.J. (1996). Dissonant heritage: the management of the past as a resource in conflict. Chichester: Wiley.

19. Wight C. (2006). Philosophical and methodological praxes in dark tourism: controversy. contention and the evolving paradigm. Journal of Vacation Marketing 12(2), 119-129. DOI: $10.1177 / 1356766706062151$.

20. Cohen E.H. (2011). Educational dark tourism at an in Populo Site: The Holocaust Museum in Jerusalem. Annals of Tourism Research 38(1), 193-209. DOI: 10.1016/j.annals. 2010.08.003.

21. Cooper M. (2006). The Pacific War Battlefields: tourist attractions or war memorials? International Journal of Tourism Research 8(3), 213-222. DOI: 10.1002/jtr.566.

22. Winter C. (2009). Tourism, social memory and the Great War. Annals of Tourism Research 36(4), 607-626. DOI: 10.1016/ j.annals.2009.05.002.

23. MacCannell D. (2012). On the ethical stake in tourism research. Tourism Geographies 14(1), 183-194. DOI: 10.1080/ 14616688.2012.639387.

24. Lemelin R.H., Whyte K.P., Johansen K., Desbiolles F.H., Wilson C., Hemming S. (2013). Conflicts, battlefields, indigenous peoples and tourism: addressing dissonant heritage in warfare tourism in Australia and North America in the twenty-first century. International Journal of Culture, Tourism, and Hospitality Research 7(3), 257-271. DOI: 10. 1108/IJCTHR-05-2012-0038.

25. Dunkley R., Morgan N., Westwood S. (2011). Visiting the trenches: exploring meanings and motivations in battlefield tourism. Tourism Management 32(4), 860-868. DOI: 10.1016/ j.tourman.2010.07.011.

26. Tanaś S. (2008). The perception of death in cultural tourism. Turyzm 18(1), 51-63. [in Polish]

27. Novelli M. (2005). Niche tourism. Contemporary issues: trends and cases. Burlington: Elsevier.

28. Biran A., Hyde K.F. (2013). New perspectives on dark tourism. International Journal of Culture, Tourism, and Hospitality Research 7(3), 191-198. DOI: 10.1108/IJCTHR-052013-0032.

29. Wilson J. (2008). Prison: cultural memory and dark tourism. New York: Peter Lang Publishing.

30. Bollag B. (1999). In the shadow of Auschwitz: teaching the Holocaust in Poland. American Educator 23(1), 38-49.

31. Foley M., Lennon J.J. (1996). JFK and dark tourism: a fascination with assassination. International Journal of Heritage Studies 2(4), 198-211. DOI: 10.1080/13527259608722175.

32. Seaton A.V. (1996). Guided by the dark: from thanatopsis to thanatourism. International Journal of Heritage Studies 2(4), 234-244. DOI: 10.1080/13527259608722178.

33. Stone P., Sharpley R. (2008). Consuming dark tourism: a thanatological perspective. Annals of Tourism Research 35(2), 574-595. DOI: 10.1016/j.annals.2008.02.003. 
34. Etxeberria A.I., Asensio M., Vicent N., Cuenca J.M. (2012). Mobile devices: a tool for tourism and learning at archaeological sites. International Journal of Web Based Communities 8(1), 57-62. DOI: 10.1504/IJWBC.2012.044682.

35. Pinder D. (2005). Arts of urban exploration. Cultural Geographies 12(4), 383-411. DOI: 10.1191/1474474005eu347oa.

36. Główny Urząd Statystyczny. (2012). Database of local data. http://www.stat.gov.pl/bdl/app/strona.html?p_name=indeks. [in Polish]
37. Agencja Rozwoju Regionalnego. (2008). Strategy of the Owl Mountains Subregion. http://turystyka.dolnyslask.pl/pliki/ Strategia_Gory_Sowie.pdf. [in Polish]

38. Gubański J. (2008). Inactive railway lines in highly valuable landscapes. Prace Komisji Krajobrazu Kulturowego 10, 186196. [in Polish]

Submitted: December 17, 2013

Accepted: January 9, 2014 